\title{
Relationship of Flowering Intensity and Cropping in Fruit Species
}

\author{
Ed Stover
}

AdDitional INDEX wORDS. biennial bearing, plant growth regulators, PG R, G A, gibberellic acid, cropload, thinning, return bloom, abscission, fruit set, fruit size, apples, Malus, citrus

Summary. The relationship between intensity of flowering and various aspects of cropping are reviewed for fruit species. Relatively light flowering can limit yield in most fruit species. This commonly occurs in young trees that have not achieved full production and in "off" years for varieties that display alternate bearing. When trees mature, many species will carry fruit numbers that exceed commercially desired levels, resulting in excessively small fruit and accentuating alternate bearing. The economic disadvantages of excess cropload have resulted in considerable research on fruit thinning and widespread commercial application of this practice. H eavy flowering intensity in some crop species results in economic disadvantages beyond the problems of excessive cropload and resultant small fruit size. $M$ any species flower profusely and have initial fruit set that greatly exceeds tree capacity, resulting in abscission of numerous flowers and fruitlets. Abscised organs can represent a substantial amount of carbohydrates and nutrients, compromising availability of these materials at critical periods in flower and fruit development. The potential implications of this process are best exemplified in ' $N$ avel' orange [Citrussinensis ( $L$.) 0 sbeck], where an increase in flowering beyond intermediate intensity results in a reduction in both initial fruit set and final fruit yield at harvest. In several species, there is evidence that fruit size may be reduced by excessive flowering, even when cropload is quickly adjusted to an acceptable level. These data suggest that further research on the advantages of controlling flowering intensity is warranted.

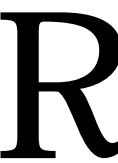

elatively light flowering limits yield in most fruit species. In contrast, when mature, many tree species produce flowers in excess of those needed to produce commercially optimal fruit loads. Frequently this results in excessive production of undesirably small fruit and subsequent alternate bearing. In some species, excessive flowering may directly reduce fruit size or even total production. This paper reviews the relationship between flowering and cropping and explores opportunities for increasing productivity through manipulating flowering. 


\section{Light flowering that limits cropping}

Light flowering and low production are commonly observed before mature bearing commences. These conditionsalso occur in the "off" years in varieties that display alternate bearing. Several studieshave demonstrated a relationship between flowering and fruiting in young trees. I $n$ a po pulation of 4 year old so ur cherry (Prunuscerasus L.) seedlings, increased flower clusters per branch generally corresponded to increased fruit per branch (lezzoni and M ullinix, 1992). Regression analysis of the published dataindicated an $\mathrm{r}^{2}$ of 0.53. For third leaf 'Gala' apple (M alusxdomestica Borkh.) acrossfour rootstocks, there was a high correlation $\left(r^{2}=0.85\right)$ between flower clusters per tree at bloom and fruit per tree at harvest (E.W. Stover, unpublished).

In mature trees, alternate bearing typically results from poor flower induction during a heavy cropping year (Westwood, 1993) with resultant poor flowering and light cropping the following year. Longley (1960) assessed the relationship between bloom and yield in mature apple trees of several varieties over a 10 -year period. $\mathrm{He}$ reported a strong linear relationship between bloom intensity and cropping, with very low yieldson trees with little bloom.

$M$ ethods such as scoring or girdling (Batjer and Westwood, 1963; Cohen, 1981; G reeneand L ord, 1978) and use of growth regulators (Estabrooks, 1993; G reene and L ord, 1978; O wens and Stover, 1999) have been widely studied as methods to increase flowering and cropping in young trees beforethey enter full bearing and in mature trees in the off-year of the alternate bearing cycle. While increases in flowering are routinely reported, effectson final cropping have been more variable, and these methods are used infrequently in commercial practice. However, the fact that increased flowering in young trees is often associated with enhanced cropping suggeststhat moreconsistent benefitsmay berealized after further study.

\section{Heavy flowering in mature trees}

$M$ ature trees frequently produce many more flowers than are needed to produce the fruit that survive to maturity, with abscission of many flowers and immature fruitlets (Table 1 ). This characteristic providesselectiveadvantage through several mechanisms (reviewed in Stephenson, 1981). G reater bloom density and duration may increase pollinator attraction and temporal synchrony with suitable pollen sources. Production of abundant ovules allows the trees to carry very large crops when resources are available, and adjust to less stressful croploads when resources are reduced. $\mathrm{H}$ igher flowering and initial fruit set also permit trees to shed weak or damaged flowers and fruitlets, without compromising the number of potential progeny. This is obviously a benefit when biotic factors damage many fruits or seeds, but in commercial production most of these stresses are minimal. In fact, there may be a significant economic cost associated with high flower production in commercial orchards.

\section{Excessive flowering that produces excessive crops, small fruit, and alternate bearing}

$\mathrm{H}$ arvestable biomass within a variety is usually strongly correlated with thenumber of fruit produced (Forshey, 1986; Johnson and $\mathrm{H}$ andley, 1989). H owever, in many fruit varieties sold for fresh consumption, the value per unit of production is much lower for small fruit than those of moderate to large size. Since competition between fruit typically results in an inverse relationship between size of fruit and number of fruit per tree (Forshey, 1986; Johnson and $\mathrm{H}$ andley, 1989), there is often a substantial incentive for reducing cropload. Theeconomic disadvantages of excessive cro pload have led to considerable research on fruit thinning and widespread commercial application of this practice. In apple, it has been demonstrated that croploads continue to increase even as flowering increases to very high levels (L ongley, 1960). Clearly, excessive flowering contributes to the problem of excessive cropping and small fruit size.

$\mathrm{H}$ eavy cropping also greatly increasesthe severity of alternate bearing in many tree crop species (M onselise and Goldschmidt, 1982). It is well established that fruit or the seeds in fruit can inhibit flowering (Chan and Cain, 1967). There is evidence that seeds and fruit produce gibberellins (GAs) (D ennis, 1976; Talon et al.,
1990) and that GAs inhibit flowering in a wide range of woody tree species (Zeevaart, 1983) suggesting that GA from fruit and seeds may be the primary factor inhibiting floral initiation and contributing to alternate bearing. There is some evidence that heavy flowering may contribute directly to alternate bearing, regardless of cropping. It is reported that a very heavy bloom in apples(snowball bloom) was sufficient to induce alternate bearing even when postbloom thinners effectively adjusted cropload (Williams, 1979). This may be due largely to GA produced by developing seeds before abscission. H owever, since $\mathrm{GA}$ is also produced by flowers, at least in apple, excess flowering may contribute directly to alternate bearing ( $M$ arino and Greene, 1981).

\section{Excessive flowering that compromises cropping}

$\mathrm{H}$ eavy flowering intensityin some crop species results in economic disadvantages beyond the well-recognized problems of small fruit size and alternatebearing dueto excessivecropload. Profuse flowers and abscising fruitlets represent a substantial loss of carbohydrates and nutrients, and this loss may compromise theselimited resources at critical periods of flower and fruit development. Percentage of flowers setting fruit typically declines as flowering intensity increases ( $D$ arnell and D avies, 1990; Guardiola et al., 1984; Knight, 1980), which in part reflects greater competition between flowers for resources. Evidence of deleterious competition during flowering and early fruit growth has been documented in several species. In 'Gala' apple, hand thinning at full bloom gave $16 \%$ greater mean fruit weight than hand thinning 3 to 4 weeks later (M cArtney et al., 1996). In 'N avel' orange, GA reduced flowering by $40 \%$ and had no effect on cropload, but increased fruit size compared to controls (E.W. Stover and L.G. Albrigo, unpublished). In 1996 'Empire' apple thinning trials in eastern $\mathrm{N}$ ew York, there were 36 cases ( out of 276 total trees) where pairs of trees with the same treatment within an experiment had similar ( $\pm 5 \%)$ final croploads but bloom per unit trunk cross-sectional area (TCA) that differed by more than $20 \%$ (E.W. Stover, unpublished). When data from these pairs of trees were analyzed, trees with higher bloom intensity were found to 
Table1. Percentageof femal eflowersresulting in harvestablefruitin an arrayof fruit species. (excerpted from Stephenson, 1981).

\begin{tabular}{ll}
\hline Species & $\begin{array}{l}\text { Female flowers that } \\
\text { produce maturefruit (\%) }\end{array}$ \\
\hline Apple (M alus xdomestica Borkh.) & $0.2-25.9$ \\
Peach [Prunuspersica (L.) Batsch] & $16.4-32$ \\
Plum (Prunusxdomestica L.) & $0-25$ \\
Orange [Citrussinensis(L.) O sbeck] & $0.2-1.0$ \\
M ango (Mangifera indica L.) & $<0.1-0.4$ \\
Avocado (Persea americana M ill.) & $<0.1$ \\
\hline
\end{tabular}

Table2. C omparison of fruitsizefrom 1996E astern N ew Y ork 'E mpire' apple thinning trial sin which treesreceiving sametreatment had final cropload within $5 \%$ but bloom density differing by greater than $20 \%$ (E.W. Stover, unpublished data).

\begin{tabular}{|c|c|c|c|}
\hline & $\begin{array}{l}\text { Flowering intensity } \\
\left(\text { bloom } / \mathrm{cm}^{2} \text { T CA }\right)^{2}\end{array}$ & $\begin{array}{l}\text { Final cropload } \\
\text { (fruit/cm² }^{2} \text { TCA) }\end{array}$ & $\begin{array}{c}\text { Mean fruit wt } \\
(\mathrm{g})^{\mathrm{x}}\end{array}$ \\
\hline High bloom & 15.6 & 11.4 & 148 \\
\hline Low bloom & 10.9 & 11.4 & 158 \\
\hline Significance & 0.0001 & NS & 0.001 \\
\hline
\end{tabular}

2TCA = trunk cross-sectional area, $1 \mathrm{bloom} / \mathrm{cm}^{2} \mathrm{TCA}=6.45 \mathrm{bloom} / \mathrm{inch}^{2} \mathrm{TCA}$

y1 fruit/ $\mathrm{cm}^{2}$ TCA $=6.45$ fruit/ inch ${ }^{2}$ TCA.

$\times 28.4 \mathrm{~g}=1.0 \mathrm{oz}$.

haveproduced significantlysmaller fruit (Table 2). While these results suggest that the competition resulting from higher flower number and initial fruitlet set compromised fruit size, it should be noted that the experiments were not designed to answer this question. It could be argued that trees with higher bloom but similar yield were inherently weaker trees.

Economic disadvantages of excessive flowering have been best documented in Spain in ' $\mathrm{N}$ avel' orange, where an increase in flowering beyond intermediate intensity resulted in a reduction in both initial fruit set and final fruit numbers at harvest (Fig. 1) (Guardiola et al., 1984). Similar results have been observed in Florida 'N avel' and 'Ambersweet' orange (E.W. Stover and L.G. Albrigo, unpublished). Experiments are underway to determine the economic benefits of using winter applications of $\mathrm{GA}_{3}$ to reduce flowering intensity in a range of Florida citrus (CitrusL.) varieties.

Reduced total cropping with increased flowering is seldom reported. $\mathrm{H}$ owever, few published studies have explored this possibility or even included relevant data. In a study using potted rabbiteyeblueberry (Vaccinium ashei R eade) bushes, one of three cultivars showed a decline in production as flowering was enhanced through greater chilling ( $D$ arnell and $D$ avies,
1990) al though time of flowering was also influenced. While this may not be typical of blueberries(F.S. D avies, personal communication), it does indicate that an inverse relationship between flowering and yield isnot unique to citrus.

\section{Biomass invested in excess flowering and aborted fruitlets}

The ratio of abscised flower and fruitlet biomass to total harvest varies greatly among and within species, and helps explain the deleterious effects sometimes observed in varieties with very heavy flowering. In Spanish 'W ash- ington $\mathrm{N}$ avel' orange, $5 \%$ to $30 \%$ of thetotal reproductivedry weight (flowers, abscised fruitlets, and harvested fruit) is represented by abscising flowers and fruitlets (calculated from Gonzales-Ferrer et al., 1984). In contrast, calculations for 'Empire' apple, from flower weightsand fruitlet growth curves (A.N . Lakso, personal communication), and data on time of fruitlet abscission (M.C. Goffinet, personal communication) suggests about $8 \%$ of reproductive fresh weight is expended on abscising reproductive organs. For very heavily flowering 'Fuerte' avocado (Persea americana M ill.) the dry weight of flowers was $12.8 \mathrm{~kg} /$ tree $(28.2 \mathrm{lb} /$ tree) which was estimated to be more than half of the dry weight of harvested fruit (T rochoulias, 1991). If values for abscising avocado fruitlets were included (T.L. Davenport, personal communication), the proportion of abscising reproductive biomass would substantially exceed $35 \% \mathrm{H}$ igh metabolic rate of flowers and young fruitlets (Bustan and Goldschmidt, 1998) may further increase the significance of this excess reproductive effort in total carbon balance.

\section{Conclusion}

Theeconomicsignificance of light flowering and low cropping in young and alternate bearing trees is widely recognized, as are the disadvantages of excessive cropping in mature trees of

Fig. 1. Effect of flowering intensity on initial fruit set (dashed line in tens of fruitlets) and final fruit number at harvest (solid line) for 'W ashington Navel' orange in Spain (from G uardiola et al., 1984).

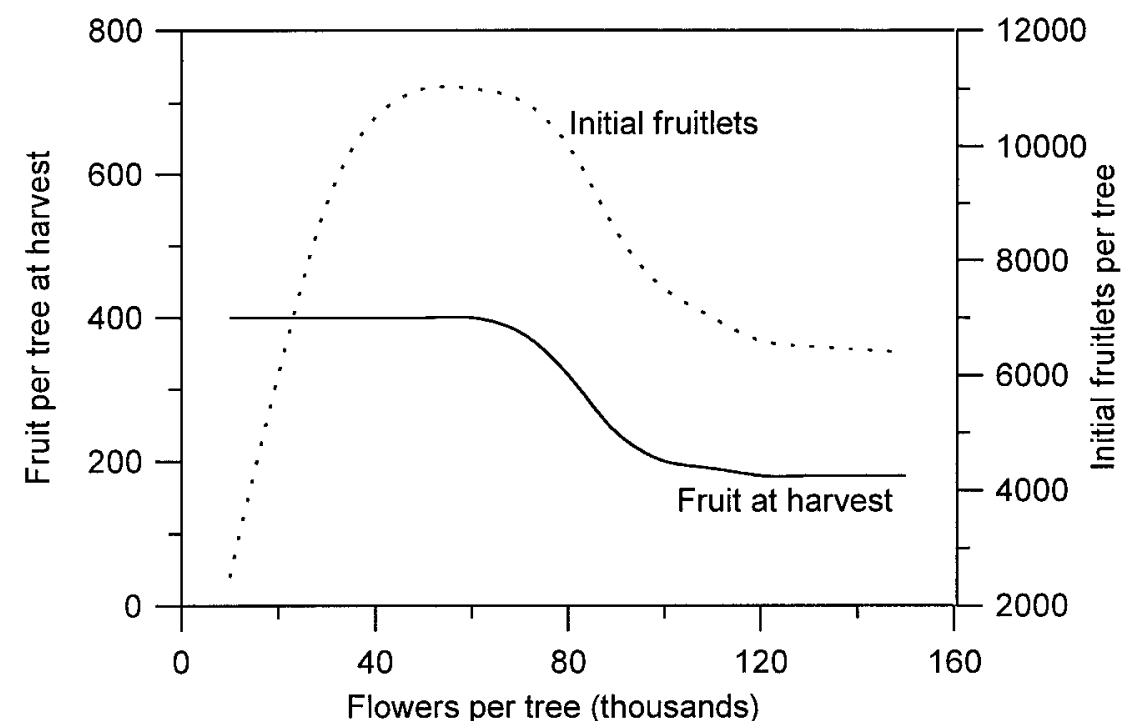


many species. While relatively little research has been conducted on the direct effects of heavy flowering, there isevidence that theresultant early competition may compromise fruit size even when cropload isquickly adjusted to acceptable levels. Some citrus species are known to display reduced fruit and yield per tree as flowering exceeds intermediate levels, and there is evidence that this is not unique to citrus.

Thesubstantial benefits of a modest surplusin reproductiveeffort should not be overlooked. For example, some excess in flowering and/ or initial fruit set is beneficial for: adjusting cropload through abscission of weak or damaged fruit (Stephenson, 1981); producing extra flowers as insurance against frost; and reducing clustered flowers (as in pome fruits) to a single fruit for better size and color. $\mathrm{H}$ owever, it appears that deleterious effects of excessive flowering are common in at least some species, and there may be substantial economic incentives to develop cultural practices for achieving optimal flowering (or selecting varieties that have more moderate flowering). Given the great disparities in excess reproductive effort among species, it is likely that efforts to achieve consistent moderate flowering will be most important where a large proportion of biomass is lost in flowers and abscising immature fruit.

\section{Literature cited}

Batjer, L.P. and M.N. Westwood. 1963. Effects of pruning, nitrogen, and scoring on growth and bearing characteristics of young D elicious apple trees. Proc. Amer. Soc. H ort. Sci. 82:5-10.

Bustan, A. and E.E. Goldschmidt. 1998. Estimating the cost of flowering in agrapefruit tree. Plant Cell Environ. 21:217224.

Chan, B.G. and J.C. Cain. 1967. Effect of seed formation on subsequent flowering in apple. Proc. Amer. Soc. H ort. Sci. 91:6368.

Cohen, A. 1981. Recent developments in girdling of citrus trees. Proc. Intl. Soc. Citricult. 1:196-199.

D arnell, R.L. and F.S. D avies. 1990. Chilling accumulation, budbreak, and fruit set of young rabbiteye blueberry plants. $\mathrm{H}$ ortScience 25:635-638.

Dennis, F.G. 1976. Gibberellin-like substances in apple seeds and fruit flesh. J. Amer. Soc. H ort. Sci. 101:629-633.

Estabrooks, E.N. 1993. Paclobutrazol sprays reduce vegetative growth and increase fruit production in young $\mathrm{M} \mathrm{Cl}$ ntosh apple trees. Can. J. Plant Sci. 73:11271135.

Forshey, C.G. 1986. Chemical thinning of apples. N.Y. Food and Life Sci. Bul. 116. N.Y. State Agr. Expt. Sta., Geneva.

Gonzales-Ferrer, J., M. Agusti, and J.L. Guardiola. 1984. Fruiting pattern and retranslocation of reserves in the $\mathrm{N}$ avel ate and W ashington $\mathrm{N}$ avel oranges. Proc. I ntl. Soc. Citricult. 1:194-200.

Greene, D.W. and W.J . L ord. 1978. Evaluation of scoring, limb spreading and growth regulators for increasing flower bud initiation and fruit set on young 'Delicious' apple trees. J. Amer. Soc. H ort. Sci. 103:208-210.

Guardiola, J.L., F. Garcia-M ari, and M. Agusti. 1984. Competition and fruit set in the Washington navel orange. Physiol. Plant. 62:297-302.

Iezzoni, A.F. and C.A. M ulinix. 1992. Yield components among sour cherry seedlings. J . Amer. Soc. H ort. Sci. 117:380-383.
Johnson, R.S. and D.F. H andley. 1989. Thinning response of early, mid-, and lateseason peaches. J. Amer. Soc. H ort. Sci. 114:852-855.

Knight, J.N. 1980. Fruit thinning of the applecultivar Cox'sO rangePippin. J. H ort. Sci. 55:267-273.

Longley, R.P. 1960. A study of the relationship between the amount of bloom and yield of apples. Can. J. Plant Sci. 40:52-57.

M arino, F. and D.W. Greene. 1981. Involvement of gibberellins in the biennial bearing of 'E arly $\mathrm{M} \mathrm{cl}$ ntosh' apples. J. Amer. Soc. H ort. Sci. 106:593-596.

M cArtney, S., J.W. Palmer, and H.M. Adams. 1996. C rop loading studies with 'R oyal G ala' and 'Braeburn' apples: E ffect of time and level of hand thinning. N.Z.J. Crop H ort. Sci. 24:401-407.

Monselise, S.P. and E.E. Goldschmidt. 1982. Alternate bearing in fruit trees: $\mathrm{H}$ orticultural control of alternation. $\mathrm{H}$ ort. Rev. 4:128-173.

O wens, C.A. and E.W. Stover. 1999. Vegetative growth and flowering of young apple trees in response to prohexadione calcium. H ortScience 34:1194-1196.

Stephenson, A.G. 1981. Flower and fruit abortion: proximate causes and ultimate functions. Annu. Rev. Ecol. Systematics 12:253-279.

Talon, M., M. Koorneef, and J.A.D. Zeevaart. 1990. Gibberellins in Citrus sinensis. A comparison between seeded and seedless varieties. J. Plant Growth Regul. 9:201-206.

Trochoulias, T. 1991. Dry matter partitioning of a mature avocado tree (cv. Fuerte). Austral. Avocado Grower (in press).

Westwood, M.N . 1993. Temperate-zone pomology. Timber Press, Portland, O re.

Williams, M.W. 1979. Chemical thinning of apples. H ort. Rev. 1:270-300.

Zeevaart, J.A.D. 1983. Gibberellins and flowering, p. 333-374 In: A. Crozier (ed.). The biochemistry and physiology of gibberellins. vol. 2. Praeger, N ewYork. 